\title{
Variations of grain physical properties, amylose and anthocyanin of upland red rice cultivars from East Nusa Tenggara, Indonesia
}

\author{
JENNY E.R. MARKUS ${ }^{1}$, A.S.S. NDIWA ${ }^{1}$, SHIRLY S. OEMATAN ${ }^{1}$, YOSEP S. MAU ${ }^{1,2, v}$ \\ ${ }^{1}$ Department of Agrotechnology, Faculty of Agriculture, Universitas Nusa Cendana. Jl. Adisucipto, Penfui, Kupang 85001, East Nusa Tenggara, \\ Indonesia. Tel./fax.: +62-380-881085, vemail: yosepmau@yahoo.com; yosepmau@ staff.undana.ac.id \\ ${ }^{2}$ Archipelagic Dryland Center of Excellence (Pusat Unggulan Ipteks/PUI Lahan Kering Kepulauan), Universitas Nusa Cendana. Jl. Adisucipto, Penfui, \\ Kupang 85001, East Nusa Tenggara, Indonesia
}

Manuscript received: 6 February 2021. Revision accepted: 17 February 2021

\begin{abstract}
Markus JER, Ndiwa ASS, Oematan SS, Mau YS. 2021. Variations of grain physical properties, amylose and anthocyanin of upland red rice cultivars from East Nusa Tenggara, Indonesia. Biodiversitas 22: 1345-1354. Red rice is becoming more popular nowadays due to the increasing awareness of rice consumers on its health benefits. The demands for red rice are increasing but the supply is limited, thus, local red rice cultivars can be used to fill this gap. Optimal use of local rice germplasm requires a comprehensive evaluation of their traits, and the genotypes having the most desirable traits can be selected for direct use. Several upland red rice cultivars from East Nusa Tenggara Province have been evaluated for various traits while their grain properties are still unrevealed. Information on grain properties is important, both for consumer preference and rice breeders. This study aimed to elucidate the grain physical properties, amylose, and anthocyanin of upland red rice germplasm from ENT Province, and to identify genotypes with the most desirable characters for further employment. Eighteen rice genotypes were used in this study. They were cultivated in the field, and the harvested grains were analyzed in the laboratory. Both ANOVA and descriptive statistics were used for data analysis. Substantial variations were observed on all variables, except the chalky grain percentage. The kernel length of tested genotypes was classified as long, medium, and short while the kernel shapes were slender, medium, and bold. Most tested genotypes had high head rice percentage and low to medium percentages of large and small broken kernels. Chalky grain was almost absent. Amylose content ranged from $1.0 \%$ to $28 \%$ while anthocyanin was about $1.0-20 \mathrm{mg} / 100 \mathrm{~g}$. The evaluated genotypes were clustered into three main groups. Percentages of large and small broken kernels, and amylose content were mostly responsible for the observed variations among the rice genotypes. The red rice genotypes were diverse in the studied characters, thus, those with desirable grain characters are useful for further development and utilization.
\end{abstract}

Keywords: cluster analysis, diversity, healthy food, local germplasm, pigmented rice

\section{INTRODUCTION}

Upland rice is the second most important staple food crop, after maize, in East Nusa Tenggara (ENT) Province, Indonesia (BPS NTT 2020). Upland rice is most adaptable to this semi-arid climatic region as compared to the irrigated lowland rice. ENT Province is rich in upland rice germplasm with high diversity as revealed by their agromorphological characters and kernel pigment (Mau et al. 2017).

Two types of pigmented rice are commonly known, namely the rice with a reddish-grain color known as red rice and that with a purplish grain color known as black rice (Mardiah et al. 2017). Both rice types are cultivated in rain-fed upland and irrigated lowland agro-ecosystems. Pigmented upland rice from ENT Province has long been cultivated and used by the local farmer communities as a staple food and mostly for customary ceremonies, where the pigmented rice is considered the most valuable food to serve. This valuation is based on the local knowledge of the high nutritional and medicinal properties of the rice. The introduction of superior/improved varieties, however, has caused most local rice cultivars to become vulnerable to extinction.
Pigmented rice is now becoming more popular due to the rising awareness of rice consumers on its nutritional and health properties. Compared to the common white rice, pigmented rice such as red rice contains higher nutrient contents such as B vitamins, dietary fiber, essential mineral elements, and anthocyanins (Tsuda et al. 2002; Zhao et al. 2004; Priya et al. 2019). The color of red rice comes from anthocyanins contained in the pericarp and aleurone layer, and the anthocyanin levels determine the red color intensity (Abdel-Aal et al. 2006; Muntana and Prasong 2010; Suliartini et al. 2011). Anthocyanin compounds have been known to provide medicinal properties such as antioxidant which can lower the risk of cancer and prevent vascular diseases like hypertension and heart attack, protect against type 2 diabetes, etc. (Hyun et al. 2004; Pojer et al. 2013; Shao et al. 2014; Chen et al. 2018; Priya et al. 2019). The above mentioned added-value properties make it plausible to consider pigmented rice as high valued rice genotype that needs to be promoted for its extensive cultivation and utilization.

Although the demand for pigmented rice is increasing nowadays, the supply in the market is still limited. This would have happened as most rice farmers are still cultivating the common 'white' rice varieties while the 
superior pigmented rice varieties, especially red rice, are only a few (IAARD 2012; Indonesian Ministry of Agriculture 2009 a, b) and thus limitedly available to the local farmers. Therefore, local pigmented rice cultivars can be used to fill this gap. The local genotypes that contain desirable traits can be selected and then extensively cultivated and used to meet the red rice demands.

ENT Province is rich in pigmented rice cultivars with high diversity on many agro-morphological related traits (Mau et al. 2017; 2018, 2019, 2020; Ndiwa and Mau 2019) but their grain physical characters and nutritional contents are still unrevealed. Information on these characters will be useful for the promotion of this rice germplasm to attract the consumer's preference. The grain physical properties and nutritional contents (especially amylose and anthocyanin) are important aspects related to the rice consumer's preference (Delwiche et al. 1995; Santika and Rozakurniati 2010). Further, information on grain properties is important for selecting the best genotypes, which can be employed as genetic resources for breeding purposes.

The present study aimed to determine the grain physical properties, amylose, and anthocyanin contents of local upland red rice cultivars from East Nusa Tenggara Province, and to reveal the genetic diversity of the germplasm based on their grain characters. The results will be useful to identify the most preferable cultivars for direct use and also for the development of improved red rice varieties.

\section{MATERIALS AND METHODS}

\section{Study area and plant materials}

Rice grain samples used in this study were harvested from the Field Laboratory of Archipelagic Dryland Center of Excellence, Universitas Nusa Cendana, West Timor, Indonesia (10.15432 S, $123.66997 \mathrm{E}, \sim 110 \mathrm{~m}$ asl, Alvisol). Eighteen upland red rice genotypes were used, consisted of 17 local cultivars (ADN-04, ALR-01, MGR-01, MK-01, NGR-011, NGR-012, PAU-01, PK-01, PM-01, PKP-01, PMK-01, SBD-05, SLT-01, TLB-04 and TLB-05) and a check variety (Aek Sibundong). The local genotypes were a germplasm collection obtained from various districts of Flores, West Timor, Sumba, Alor, Adonara, and Solor Islands of East Nusa Tenggara Province while Aek Sibundong was obtained from the Indonesian Center for Rice Research (ICRR), Sukamandi, West Java.

The grains samples used in the present study were sundried (to approximate 12\% moisture content) and stored for two months at room temperature before laboratory analysis. The study was conducted in the Post-Harvest Technology Laboratory and Biosains Laboratory of Universitas Nusa Cendana, Indonesia. The dehusked rice samples were evaluated for the following variables: kernel length, kernel width, kernel shape, percentage of head rice, percentage of large broken kernel (large broken), percentage of small broken kernel (small broken), percentage of chalky grain (grain chalkiness), amylose content, and anthocyanin content.

\section{Assessment of grain physical properties}

The dehusked grains (kernels) were used for the determination of the grain physical characters. Three lots of rice kernels, 10 kernels per lot, were randomly taken from the prepared grain samples of each genotype and measured for kernel length and kernel width by using a dial clipper. The rice length size was then classified into four categories (Juliano 1993; Santika and Rozakurniati 2010), i.e., extralong $(\mathrm{EL}>7.50 \mathrm{~mm})$, long $(\mathrm{L}=6.61-7.50 \mathrm{~mm})$, medium $(\mathrm{M}=5.51-6.60 \mathrm{~mm})$, and short $(\mathrm{S}=\leq 5.50 \mathrm{~mm})$.

Grain/kernel shape was determined as the ratio of the kernel length and the kernel width (L/W ratio), as shown in the following formula (Santika and Rozakurniati 2010):

$$
\text { Grain/Kernel Shape }=\frac{\text { Kernel length }}{\text { Kernel width }}
$$

The kernel shape was classified into four categories, i.e., slender $(\mathrm{S}=>3.0)$, medium $(\mathrm{M}=2.1-3.0)$, bold $(\mathrm{B}=$ 1.1-2.0) and round (<1.0) (Juliano 1993).

Head rice, large broken, and small broken were determined based on the IRRI (1988) and the Indonesian National Standard (SNI) 6128:2008 (BSN 2008). Rice chalkiness was determined by visually estimating the percentage of chalkiness of the grain samples, and the mean percentage of chalky grains was calculated. The rice chalkiness was then categorized into high $(\mathrm{H}=>20 \%)$, medium $(\mathrm{M}=$ $11-20 \%)$, Low ( $\mathrm{L}=<10 \%)$, and clear (0\%) (IRRI 1988).

\section{Determination of amylose content}

An Iodine colorimetric method (IRRI 1988; Lalel et al. 2009) was employed to determine the amylose content of evaluated rice genotypes. $100 \mathrm{mg}$ rice flour was put into $100 \mathrm{~mL}$ volumetric flask and added with $1 \mathrm{~mL} \mathrm{95 \%} \mathrm{ethanol}$ and $9 \mathrm{~mL} \mathrm{NaOH} 1 \mathrm{~N}$. The mixture was heated at boiling water for $10 \mathrm{~min}$. to allow the formation of gel and then allowed to cool for one hour. The gel mixture was then diluted using $\mathrm{ddH}_{2} \mathrm{O}$ to $100 \mathrm{~mL}$, and $5 \mathrm{~mL}$ was pipetted and put into another $100 \mathrm{~mL}$ volumetric flask containing $60 \mathrm{~mL}$ of water, then added with $1 \mathrm{~mL}$ of $1 \mathrm{~N}$ acetic acid and 2 $\mathrm{mL}$ of $2 \%$ Iodine and diluted to a $100 \mathrm{~mL}$ volume. The solution was shaken and allowed to stand for $20 \mathrm{~min}$., then the absorbance was measured by using a spectrophotometer (UV-Vis, Model 6405, Jenway Ltd., Essex, England) at $625 \mathrm{~nm}$ wavelength. Amylose content was determined using the standard curve of amylose (Juliano 1979).

Based on the amylose content, the tested genotypes were further classified into several flavor groups, i.e., $<10 \%$ (glutinous), $10-<20 \%$ (extra fluffier), 20-25\% (fluffier) and > 25\% (dry-flavored) (BSN 2008; Santika and Rozakurniati 2010).

\section{Determination of total anthocyanin content}

Extraction of total anthocyanin was performed according to Lee et al. (1998). A total of $5 \mathrm{~g}$ of rice flour was extracted 5 times each with $10 \mathrm{~mL} 15 \%$ acetic acid in methanol for $30 \mathrm{~min}$. by using a shaker. The extract mixture was then centrifuged at $12,000 \mathrm{rpm}$ at room temperature for $10 \mathrm{~min}$. The supernatant was then evaporated under a vacuum condition at $40^{\circ} \mathrm{C}$ to let it dry. 
This dry extract was dissolved with $25 \mathrm{~mL}$ of methanol and subjected to further analysis.

Total anthocyanin was determined based on the method as follows (Prior et al. 1998; Giusti and Wroistad, 2000). $0.05 \mathrm{~mL}$ extract solution was inserted into 2 test tubes. The first tube was added with a $4.95 \mathrm{~mL} \mathrm{KCl}(0.025 \mathrm{M}, \mathrm{pH} 1.0)$ buffer solution, and the second was added with a $4.95 \mathrm{~mL}$ $\mathrm{CH}_{3} \mathrm{COONa}(0.4 \mathrm{M}$, pH 4.5$)$ buffer solution. Adjustment of $\mathrm{pH}$ in the preparation of $\mathrm{KCL}$ and $\mathrm{CH}_{3} \mathrm{COONa}$ buffer solutions was done using a concentrated $\mathrm{HCl}$. The prepared buffer solutions were kept at room temperature for 15 minutes, and then the absorbance of both $\mathrm{pH}$ treatments was measured by using a spectrophotometer (UV-Vis Spectrophotometer, Model 6405, Jenway Ltd., Essex, England) at $520 \mathrm{~nm}$ and $700 \mathrm{~nm}$ wavelength. The absorbance value was calculated using the formula $\mathrm{A}=$ $\left(\mathrm{A}_{520}-\mathrm{A}_{700}\right)_{\mathrm{pH}} 1-\left(\mathrm{A}_{520}-\mathrm{A}_{700}\right)_{\mathrm{pH}}$ 4.5. Anthocyanin concentrations were determined as cyanidin-3-glycosides using a molar extinction coefficient of $29600 \mathrm{~L} \mathrm{~cm}^{-1}$ and a molecular weight of 448.8. Anthocyanin concentration (mg $\left.\mathrm{mL}^{-1}\right)=(\mathrm{A} \times \mathrm{MW} \times \mathrm{DF} \times 1000) /(\mathrm{E} \times 1)$, where $\mathrm{A}$ is the absorbance, $\mathrm{MW}$ is the molecular weight (448.8), DF is the diluting factor $\left(5 \mathrm{~mL} \quad 0.05 \mathrm{~mL}^{-1}\right)$ and $\mathrm{E}$ is the molar extinction coefficient $\left(29600 \mathrm{~L} \mathrm{~cm}^{-1}\right)$.

\section{Data analysis}

Observed data of the grain shape, percentage of head rice, percentage of large broken kernel, percentage of small broken kernel, and percentage of chalky grain were analyzed descriptively, while the kernel length, kernel width, amylose content and anthocyanin content were subjected to analysis of variance following a Completely Randomized Design to see the genotype effect. A post hoc DMRT test $(5 \%)$ was used to determine the differences between the genotype means. Cluster analysis was also carried out to group the evaluated rice genotypes based on observed variables. Principal Component Analysis (PCA) was performed to determine variables mostly responsible for the observed variations in the data set. The Genstat
Version 12 (VSNi 2009) was used to perform the ANOVA while PAST program (Hammer et al. 2001) version 4.03 was used for cluster and PCA analysis.

\section{RESULTS AND DISCUSSION}

\section{Kernel length and width}

The evaluated rice genotypes varied in both kernel length and kernel width (Figure 1). The kernel length ranged from $4 \mathrm{~mm}$ to $7 \mathrm{~mm}$, that of 11 genotypes was about $6 \mathrm{~mm}$, that of four genotypes was $4-5 \mathrm{~mm}$ and the other three genotypes was about $7 \mathrm{~mm}$. The evaluated genotypes were classified into three kernel size categories, i.e., long $(\mathrm{L}=6.61-7.50 \mathrm{~mm})$, medium $(\mathrm{M}=5.51-6.60$ $\mathrm{mm}$ ), and short ( $\mathrm{S}=<5.50 \mathrm{~mm}$ ) (Santika and Rozakurniati 2010). Genotypes ADN-04, PMK-01, and TLB-05 were classified as long kernel, the check variety Aek Sibundong and local cultivars ALR-01, MGR-01, NGR-011, NGR012, PAU-01, PK-01, PKP-01, PM-01, SBD-05, and SLT01 had medium kernel and the local cultivars ISN-02, MK01, SBR-01, and TLB-04 were short kernel.

Kernel width of tested genotypes only slightly varied (Figure 1). The majority of the genotypes (14 genotypes) had almost the same rice kernel width of about two mm. Four local genotypes (ADN-04, ISN-02, PAU-01, and TLB-04) exhibited about three mm kernel length. This germplasm collection had a low diversity kernel width trait. However, this trait is useful to determine the shape of the rice kernel as presented below.

\section{Kernel length to width ratio (kernel shape)}

The kernel shape was determined as the ratio between kernel length (L) and kernel width (W) (Juliano 1993). Calculated L/W ratios (kernel shapes) are presented in Figure 2. The results showed that the rice genotypes varied in kernel shape. They were classified into slender, medium, and bold kernel shapes.

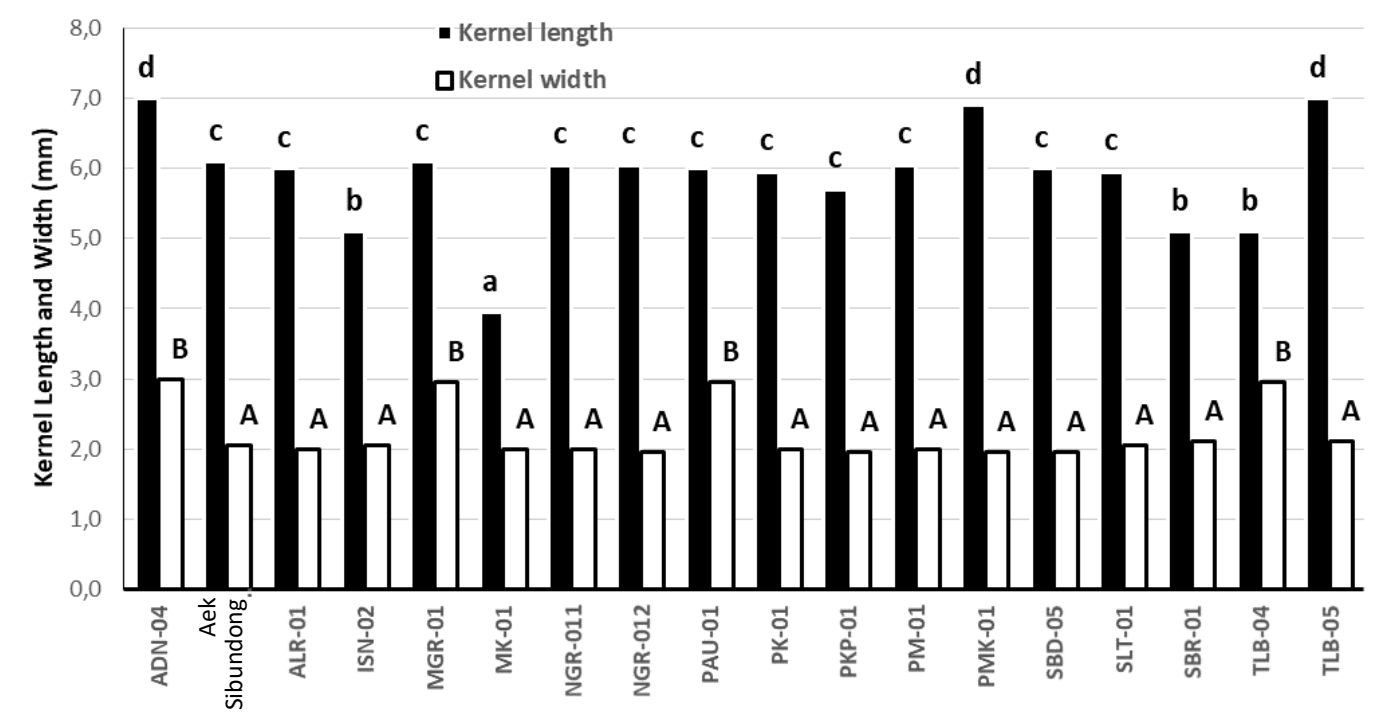

Figure 1. Distribution of kernel length and kernel width of upland red rice genotypes from East Nusa Tenggara, Indonesia. Different superscript letters denote significant difference $(\mathrm{DMRT}, \mathrm{p}<0.05)$ on kernel length, different capital letters denote significant difference (DMRT, $\mathrm{p}<0.05$ ) on kernel width 


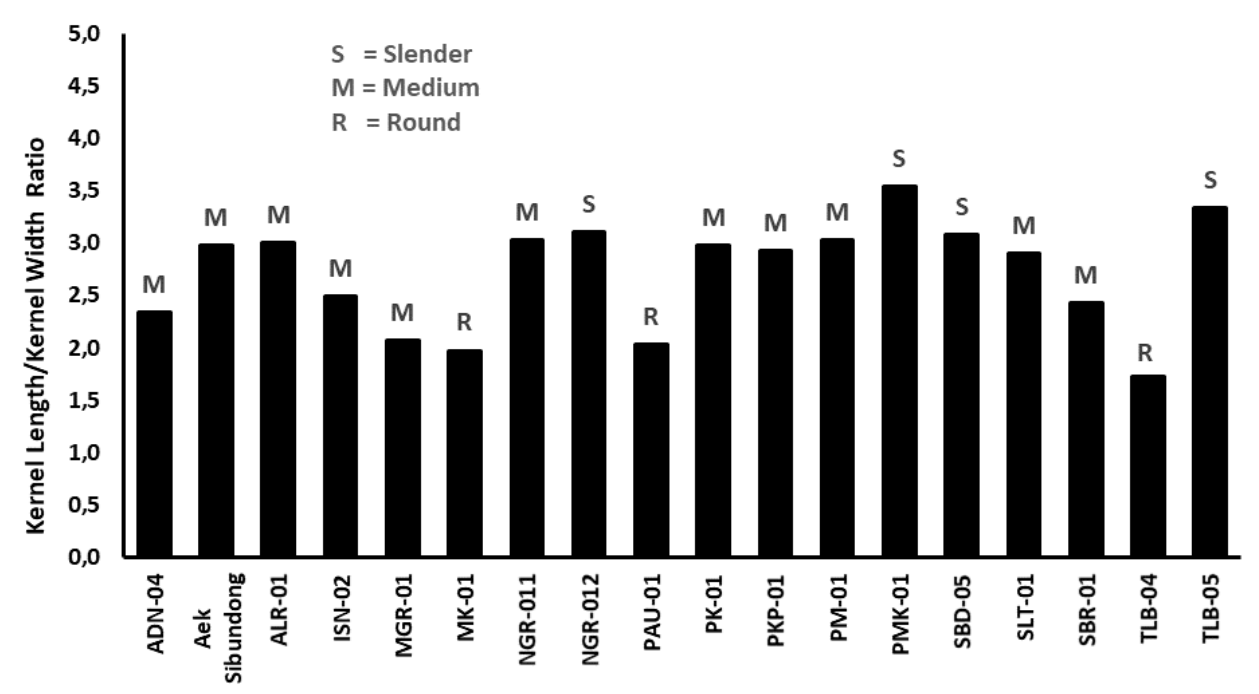

Figure 2. Distribution of kernel shapes of upland red rice genotypes from East Nusa Tenggara, Indonesia

Figure 2 shows that 11 genotypes (ADN-04, Aek Sibundong, ALR-01, ISN-02, NGR-011, MGR-01, PK-01, PKP-01, MK-01, SBR-01, and SLT-01) had medium kernel shape, four genotypes (NGR-012, PMK-01, SBD-5 and TLB-05) had slender kernel shape and three genotypes (MK-01, PAU-01, and TLB-04) had bold kernel shape.

\section{Percentages of head rice, large broken kernel, small broken kernel, and chalky rice}

The percentage of head rice ranged from about 30 to $100 \%$ (Figure 3). Most genotypes (ADN-04, Aek Sibundong, ALR-01, NGR-011, NGR-012, PAU-01, PK01, PM-01, PMK-01, SBD-05, SBR-01, SLT-01, TLB-05) showed around $80-100 \%$ head rice. Head rice of other genotypes ranged from 30-70\%, i.e., ISN-02 (73\%), MGR$01(66 \%)$, MK-01 (47\%), PKP-01 (30\%), and TLB-04 (47\%).

The percentage of large broken kernels ranged from $0 \%$ to $57 \%$. PKP-01 produced the highest large broken kernel (57\%), followed by MGR-01 (35\%), MK-01 (33\%), and ISN-02 (18\%), respectively. The rest genotypes had below $20 \%$ large broken kernel. Six genotypes (ALR-01, PAU01, PMK-01, SBR-01, SLT-01 and TLN-05) showed no large broken kernel.

The small broken kernel was only found on four genotypes, ranging from $0 \%$ to $43 \%$. TLB-04 showed the highest percentage $(43 \%)$ followed by, respectively, MK01 (20\%), NGR-012 (12\%), and PKP-01 (13\%). The rest 13 genotypes showed no small broken kernel.

In contrast to other observed kernel physical characters, the chalky rice was almost absent in the tested genotypes. All genotypes showed no chalky kernel, except for ISN-02 which had a low category (10\%) chalky kernel.

The study results showed that most of the rice genotypes evaluated had good rice kernel physical quality as evidenced from the high percentage of head rice of most genotypes, and medium to low percentage of large and small broken kernels of most tested genotypes. Six local genotypes (ALR-01, PAU-01, PMK-01, SBR-01, SLT-01, and TLB-05) had the best kernel quality. This was indicated by a high percentage of head rice and the absence of broken kernel and chalky grain. These genotypes have the potential for direct use by the farmers or to be used as a source of genes for the selection of high kernel physical quality characters of upland red rice, which suit the consumer's preference.

\section{Amylose content}

There was a highly significant $(\mathrm{P}<0.01)$ genotypic effect on the amylose content of the studied genotypes. The amylose content widely varied from around $1.9 \%$ to $28.9 \%$ (Table 1). The evaluated genotypes were classified into waxy (1-2\% amylose) and non-waxy (>2\% amylose) rice. The non-waxy rice genotypes were further classified into very low $(2-<10 \%)$, low $(10-<20 \%)$, moderate $(20-25 \%)$, and high $(>25 \%)$ amylose content (Juliano 1971; Juliano 1979). Only PKP-01 was classified as waxy rice and the remaining 17 genotypes were categorized into non-waxy rice with an amylose content of very low (PK-01, PM-01, SLT-01, SBR-01), low (ADN-04, Aek Sibundong, MGR01, PAU-01, PMK-01, TLB-05), moderate (ALR-01, MK01, NGR-011, NGR-012, SBD-05, TLB-04) and high (ISN-02).

As the amylose content greatly determines the rice texture and taste/flavor (Delwiche et al. 1995; Santika and Rozakurniati 2010), the study results indicate that the tested genotypes may also vary in terms of rice taste/flavor quality. Based on the amylose content, the rice taste/flavor could be classified into dry-flavored (amylose content > $25 \%)$, fluffier $(20-25 \%)$, extra fluffier $(10-<20 \%)$ and glutinous $(<10 \%)$ (Santika and Rozakurniati 2010.) Of the 18 tested genotypes, one genotype was classified as 'dryflavored', six genotypes had a 'fluffier' taste, six genotypes were classified as extra fluffier taste, and the remaining five genotypes were glutinous. 


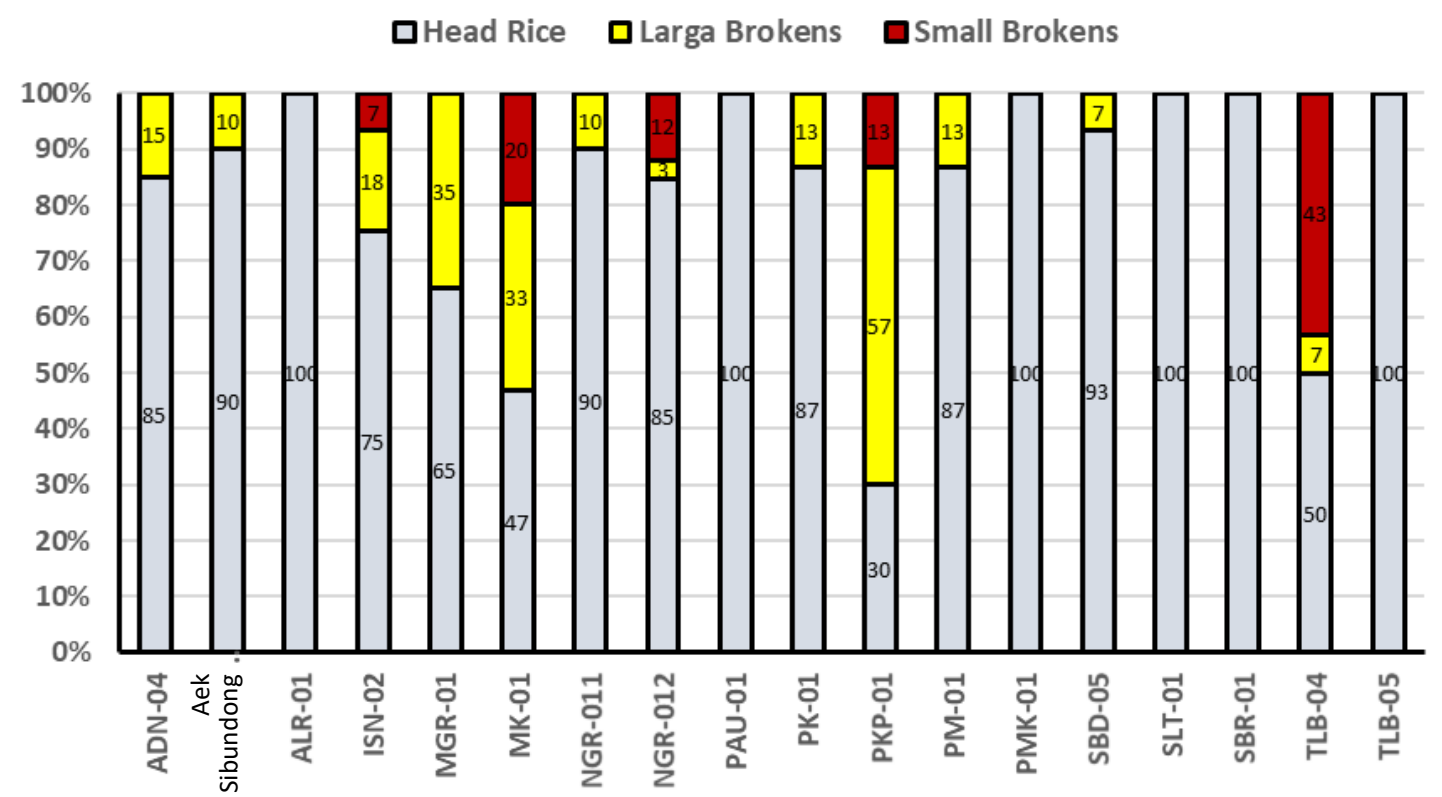

Figure 3. Distribution of head rice, large broken and small broken kernels of upland red rice genotypes from East Nusa Tenggara, Indonesia

Table 1. Amylose and anthocyanin levels of upland red rice genotypes from East Nusa Tenggara, Indonesia

\begin{tabular}{|c|c|c|c|c|c|c|}
\hline \multirow{2}{*}{ Rice genotypes } & \multicolumn{3}{|c|}{ Amylose } & \multicolumn{3}{|c|}{ Total anthocyanin } \\
\hline & Level & $\%)$ & Category & Level ( & $\mathrm{g} / \mathbf{1 0 0} \mathrm{g})$ & Category \\
\hline ADN-04 & 19.05 & $\mathrm{e}$ & Low & 1.48 & $a b c$ & Low \\
\hline Aek Sibundong & 16.93 & $\mathrm{c}$ & Low & 1.18 & ab & Low \\
\hline ALR-01 & 20.90 & $\mathrm{~g}$ & Moderate & 2.09 & $\mathrm{bc}$ & Low \\
\hline ISN-02 & 28.92 & $\mathrm{j}$ & High & 3.27 & d & Low \\
\hline MGR-01 & 18.46 & de & Low & 1.43 & $a b c$ & Low \\
\hline MK-01 & 24.14 & $\mathrm{i}$ & Moderate & 20.18 & $\mathrm{~h}$ & High \\
\hline NGR-011 & 19.88 & $\mathrm{f}$ & Moderate & 5.23 & e & Moderate \\
\hline NGR-012 & 23.53 & hi & Moderate & 1.03 & a & Low \\
\hline PAU-01 & 17.76 & $\mathrm{~cd}$ & Low & 6.24 & f & Moderate \\
\hline PK-01 & 7.35 & $\mathrm{~b}$ & Very Low & 1.96 & $a b c$ & Low \\
\hline PKP-01 & 1.91 & a & Waxy & 3.34 & d & Low \\
\hline PM-01 & 2.20 & a & Very Low & 4.98 & e & Low \\
\hline PMK-01 & 18.80 & $\mathrm{e}$ & Low & 1.88 & $\mathrm{abc}$ & Low \\
\hline SBD-05 & 22.93 & $\mathrm{~h}$ & Moderate & 1.05 & $\mathrm{a}$ & Low \\
\hline SLT-01 & 2.55 & a & Very Low & 11.99 & $\mathrm{~g}$ & High \\
\hline SBR-01 & 2.36 & a & Very Low & 5.48 & ef & Moderate \\
\hline TLB-04 & 23.94 & $\mathrm{i}$ & Moderate & 2.21 & $\mathrm{c}$ & Low \\
\hline TLB-05 & 19.18 & ef & Low & 6.11 & f & Moderate \\
\hline
\end{tabular}

Note: Different superscript letters in the same column denote significant difference (DMRT, p<0.05) amongst genotypes

\section{Total anthocyanin content}

ANOVA results showed highly significant differences $(\mathrm{P}<0.01)$ of total anthocyanin content amongst tested genotypes. The mean anthocyanin contents (Table 1) varied greatly from $1.05 \mathrm{mg} / 100 \mathrm{~g}$ to $20.18 \mathrm{mg} / 100 \mathrm{~g}$. Total anthocyanin of tested genotypes was categorized into high $(>10 \mathrm{mg} / 100 \mathrm{~g})$, moderate $(5-10 \mathrm{mg} / 100 \mathrm{~g})$ and low $(<5$ $\mathrm{mg} / 100 \mathrm{~g})$.

Only two genotypes (MK-01 and SLT-01) exhibited high anthocyanin levels, four genotypes (PAU-01, PM-01, SBR-01, TLB 05) showed moderate anthocyanin level while the remaining 12 genotypes had low anthocyanin level (Table 1).

Even though most of the genotypes produced only low anthocyanin levels, they are a good source of functional food for consumers with degenerative diseases such as diabetes mellitus, hypertension, or other metabolic disorders. Meanwhile, tested genotypes with high and moderate anthocyanin levels are potential genetic resources that can be used to meet the needs of rice consumers for functional healthy rice food products, as well as to assemble improved varieties of pigmented upland rice. 


\section{Cluster analysis and Principal Component Analysis results}

The Unweighted Pair Group Method with Arithmetic Mean (UPGMA) using Euclidean distance was employed to perform the cluster analysis. Cluster analysis revealed that the 18 evaluated genotypes could be grouped into three main clusters based on eight-grain characters, at a truncation point of 50 (Figure 4). From left to right (Figure 4), cluster I consisted of four genotypes (TLB-04, MK-01, MGR-01, ISN-02), cluster II comprised of 13 genotypes (ALR-01， PMK-01，PAU-01，TLB-5, Aek Sibundong, NGR-011，SBD-05，AND-03，PK-01，PM-01，SLT-01, SBR-01) and cluster III was a single genotype (PKP-01) cluster. Genotypes constituting each cluster were accessions from either the same or different islands and districts in ENT Province and thus, representing the genetically diverse red rice germplasm. The local genotype PKP-01 was separated in a single distantly apart group, indicating its unique characters mostly contributed to the grouping. The unique characters included the percentages of large broken kernel and small broken kernel as well as amylose content. The grain characters mostly contributed to the observed variations of tested genotypes are described in the PCA analysis results (Figure 5).

The PCA results revealed that three principal components (PC1, PC2, and PC3) explained most of the observed variations $(97.6 \%)$, where component $1(76.4 \%)$ and component 2 (14.9\%) accounted for $91.3 \%$ while component 3 contributed only $6.3 \%$ for the variations. Figure 5 shows the scatter plots of PCA involving eightgrain characters of genotypes evaluated, and the characters mostly responsible for the maximum variances in the principal components are shown.

PCA results revealed that the grain characters mostly responsible for maximum variability in $\mathrm{PC} 1$ were the percentage of large broken kernel and the percentage of small broken kernel as indicated by high positive loading factors of, respectively, 0.897 and 0.663 . Kernel width (loading factor 0.166) and anthocyanin (0.168) provided only a small contribution to the variations (Figure 5). Small broken kernel (loading factor 0.705), amylose (0.645), and kernel width (0.209) were responsible for maximum variability in PC2. Amylose content was mostly responsible for maximum variability (loading factor 0.760 ) in PC3. Thus, the grain characters mostly responsible for the observed variations in the tested genotypes included the percentage of large broken kernel, the percentage of small broken kernel, and amylose content. The kernel width, kernel length, anthocyanin content, L/W ratio, and the percentage of head rice provided only small contributions.

Figure 4 shows that cluster I consisted of four genotypes, cluster II comprised of 13 genotypes while cluster III consisted of only one genotype. PKP-01 was clustered separately. Presumably due to its much higher percentage of large broken kernel (and thus, low percentage of head rice) and lower amylose content, as compared to other genotypes. These results are confirmed by the PCA analysis where the percentage of large broken kernel, the percentage of small broken kernel, and amylose content were mostly responsible for the maximum variability in each principal component. Thus, performing cluster analysis and PCA analysis altogether in this study is useful for dissecting the level of diversity of tested genotypes in more detail such as the most significant traits of the rice genotype's cluster so that they can be selected and used more efficiently.

\section{Discussion}

Substantial variations of grain physical properties, amylose and anthocyanin levels in the present study indicate a wide genetic diversity of the red rice germplasm from ENT. This is in line with the previous results where the rice germplasm was found to greatly vary in agromorphological characters (Mau et al. 2017), grain yields (Mau et al. 2019; Ndiwa and Mau 2019), and biotic stresses tolerance/resistance (Mau et al. 2018; 2020). As red rice is known to possess superior traits in terms of various health benefits (Nam et al. 2006; Yawadio et al.2007; Henderson et al. 2012; Pojer et al. 2013; Banjerdpongchai et al. 2013; Shao et al. 2014; Chen et al. 2018; Priya et al. 2019), these high diversity germplasms are valuable assets to meet the varying preferences of rice consumers for healthy ricebased diets.

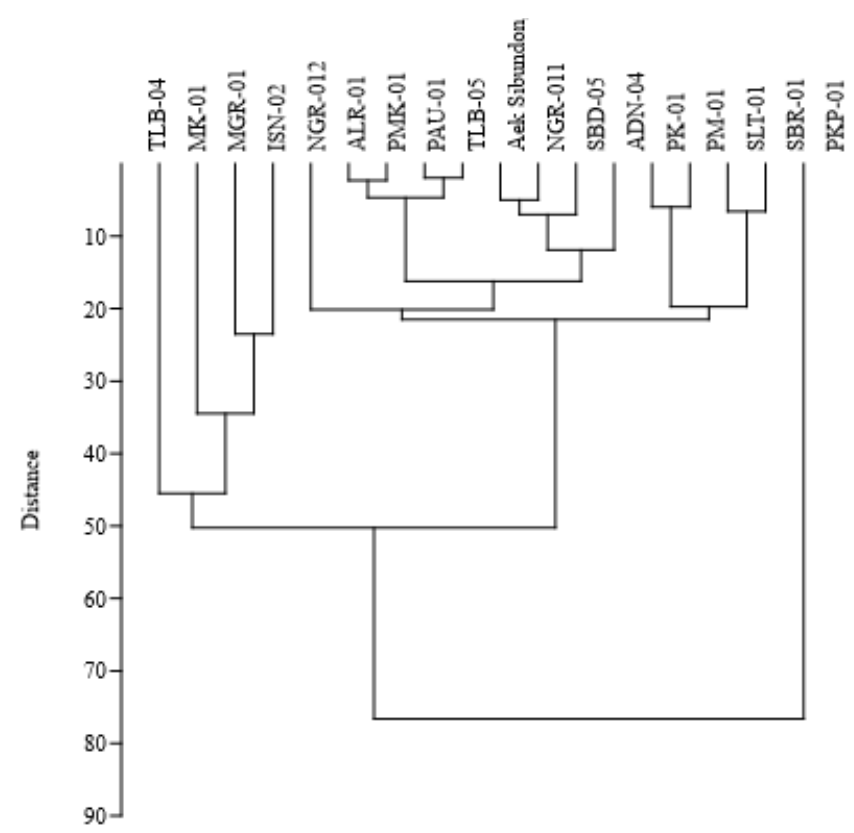

Figure 4. Dendrogram of upland red rice genotypes from East Nusa Tenggara, Indonesia based on eight-grain characters 


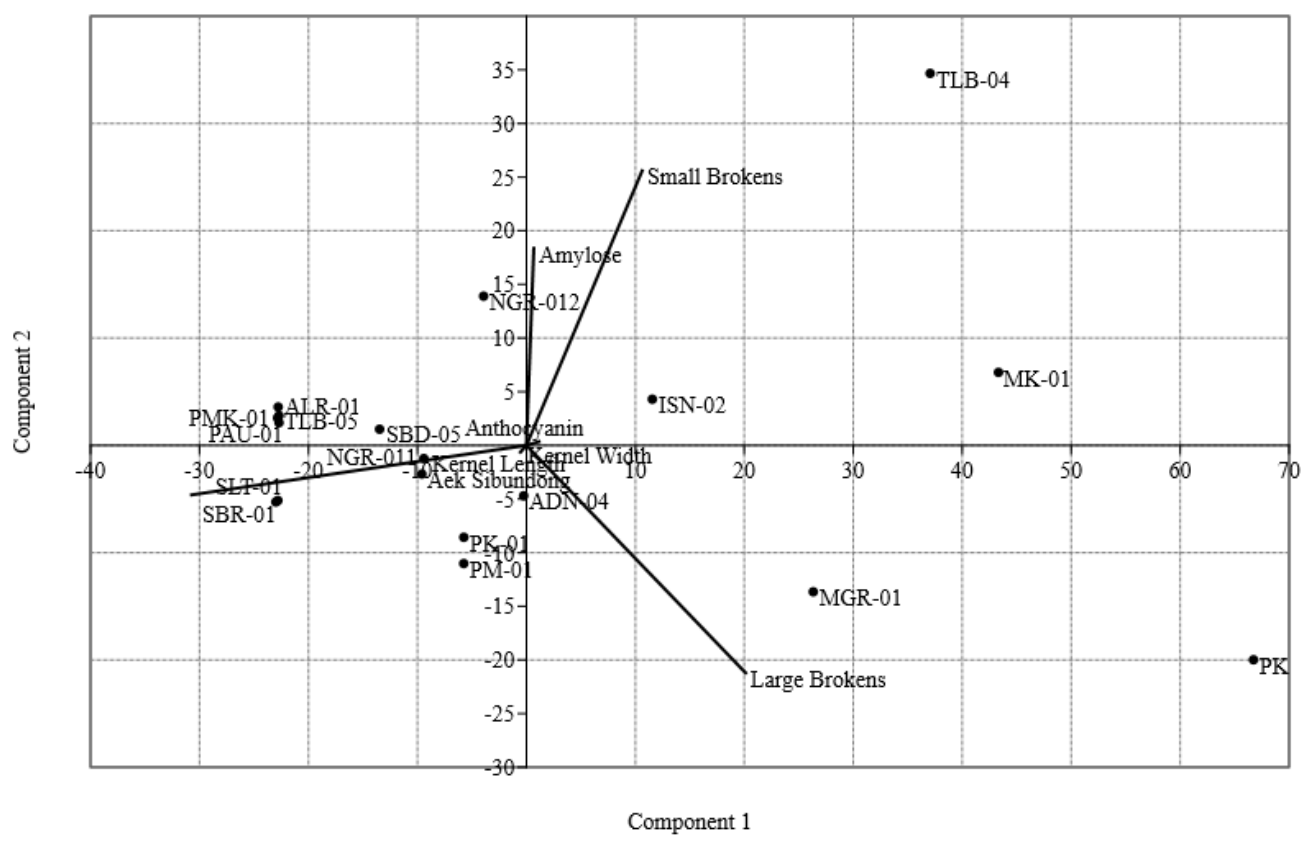

Figure 5. Scatter plots showing distribution and characters mostly responsible (PC-1 vs PC-2) for the observed variances of upland red rice genotypes from East Nusa Tenggara, Indonesia

The grain physical properties of the studied red rice genotypes were more varied as compared to those of other studies on different pigmented rice germplasm. The grain size of the present study was categorized into long, medium, and short kernel while that observed by Ponnappanet et al. (2017) was only medium size. Additionally, the grain length of red rice from South Sulawesi, Indonesia was classified as extra-long, long, and medium-size categories (Murdifin et al. 2015). The kernel length size category of the present studied is also more varied as compared to that of 14 genotypes of Indonesian red rice (Santika and Rozakurniati 2010), which fell only into long and medium categories.

The grain shapes of the studied genotypes were slender, medium, and bold, which are similar to those recorded by Bhonsle and Sellappan (2010) from 25 tested genotypes. As a comparison with other Indonesian red rice germplasm collections, Santika and Rozakurniati (2010) obtained only slender and medium kernels shapes from 14 Indonesian red rice genotypes. Similarly, Murdifin et al. (2015) recorded only slender and medium grain shapes of red rice from South Sulawesi. Ponnappan et al. (2017) also observed slender and medium grains shapes from a pigmented rice collection from India. The high variations of grain length and shapes of tested genotypes are beneficial as they can accommodate the red rice consumer's needs. In some parts of Indonesia, many rice consumers more prefer long and slender rice while those in other regions prefer more medium and short/bold rice.

The percentage of head rice was above $80 \%$ and the percentages of large and small broken kernels were medium to low in only a few genotypes. The chalky grain was almost absent. This indicates a high physical grain quality of tested rice genotypes. Almost the same range of head rice and broken rice percentages was observed in pigmented and white local rice from Yogyakarta, Indonesia (Astuti et al. 2017). The grain physical quality of the present study would provide preference and commercial values to the tested red rice germplasm.

Amylose content also substantially varied. Amylose content of tested genotypes fell almost in the same range as that of a previous study by Abdullah (2017) on several Indonesian pigmented rice varieties. Similarly, Chen et al. (2019) also recorded almost the same range of amylose content on colored rice genotypes from Wenjiang District, Sichuan Province, China. The amylose levels of tested genotypes are much highly varied as compared to a study by Bhonsle and Sellappan (2010) on 25 tested local cultivars of Goa, India, and that by Santika and Rozakurniati (2010) on Indonesian low land red rice genotypes.

Pigmented rice is usually consumed as brown rice since the intact aleurone layer of brown rice contains phenolics and anthocyanins. However, the eating quality of red rice mostly consumed as brown rice makes it difficult for consumers to consume red rice on a daily basis as with white rice, and thus, a one-time polishing process enhanced the red rice-eating quality (Mardiah et al. 2017). Further, Delwiche et al. (1995) and Santika and Rozakurniati (2010) assessed that amylose content is one of the key factors determining the cooking quality and taste of rice, thus, the eating quality and taste of rice could be predicted from the amylose content. The results showed that most of the genotypes evaluated could be classified into extra fluffier to fluffier tastes. The fluffier taste suits most Indonesian rice consumers (Santika and Rozakurniati 2010). Red rice genotypes with a 'dry-flavored' taste (high amylose content) may not be popular for most consumers, but this type of 
rice usually has a low glycemic index, which is highly recommended as healthy functional food due to its high fiber content. The red rice genotypes with glutinous taste in this study are also valuable as raw materials for stickybased culinary products, which are also favorite foods for many rice consumers in Indonesia. Thus, all the local upland red rice genotypes evaluated in the present study are beneficial depending on their allocation according to consumer's needs and preferences.

Only two genotypes contained high anthocyanin content while most of the tested genotypes produced moderate to low anthocyanin levels (1- $20 \mathrm{mg} / 100 \mathrm{~g}$ ). These results are much higher in range as compared to those of Indonesian red rice germplasms observed by Murdifin et al. (2015) (6.6 - $12.9 \mathrm{mg} / 100 \mathrm{mg})$, Widyawati et al. (2014) (<1 mg/100 g), and Hanifa et al. (2020) (2.9 $7.4 \mathrm{mg} / 100 \mathrm{~g})$, but much lower than the results of Yodmanee et al. (2011) (10 - $129 \mathrm{mg} / 100 \mathrm{~g})$ on pigmented rice genotypes from Southern Thailand. The high anthocyanin content observed by Yodmanee et al. (2011) may have been contributed by black rice genotypes included in the study. The present tested genotypes with low to moderate anthocyanin levels are still a good source of functional healthy food for rice consumers. Meanwhile, tested genotypes with high anthocyanin are potential genetic resources that can be used to meet the needs of rice consumers as well as to assemble improved varieties of pigmented upland rice with high anthocyanin levels.

Anthocyanins are polyphenol derivatives of flavonoid components in plants that can act as antioxidants, anticancer, and prevent coronary heart diseases, anemia and type 2 diabetes, etc. (Nam et al. 2006; Henderson et al. 2012; Banjerdpongchai et al. 2013; Yawadio et al.2007). Anthocyanin pigments cause red or purple color, and even black when anthocyanin content is high (Abdel-Aal et al. 2006; Suliartini et al. 2011). Red and dark blue colors caused by anthocyanin content occur mainly on rice grain pericarp and aleuron, however, they also present in other parts of the rice plant (Ichikawa et al. 2001; Kim et al. 2011).

Genetically, OSB1 gene is suggested to control anthocyanin biosynthesis in rice (Wang and Shu 2007; Shih et al. 2008; Lim and Ha 2013; Sakulsingharoj et al. 2016). Shifh et al. (2008) found differences in nucleic acid sequences of OSB1 gene in white and colored rice, respectively. Meanwhile, Sakulsingharoj et al. (2016) observed a full-length nucleic acid sequence of OSB1 gene in black rice expressing anthocyanin biosynthesis while a mutation addition of 2-bp in $O S B 1$ gene observed in the white rice caused it unable to produce anthocyanin. In addition to $O S B 1$, there are still other regulatory genes that may involve in the anthocyanin biosynthesis (Sweeney et al. 2006; Oikawa et al. 2015; Sun et al. 2018; Kim et al. 2018). This implies that differences in genetic factors are predominantly causing differences in anthocyanin levels produced by a rice germplasm collection. This situation might have occurred in the tested upland red rice germplasm from ENT. The same situation in the genetic control of anthocyanin biosynthesis may have occurred for other observed traits of the present study such as grain physical characters and amylose content but further studies are needed to confirm this presumption.

The present study results revealed highly diverse grain physical properties and also nutritional contents of upland red rice genotypes from ENT, Indonesia. Grain physical properties and nutritional content variations of pigmented rice from other parts of Indonesia were reported by several authors (Santika and Rozakurniati 2010; Widyawati 2014; Murdifin et al. 2015; Abdullah 2017; Astuti et al. 2017; Hanifa et al. 2020). Thus, the high diversity of pigmented rice genotypes, more specifically red rice, in Indonesia are valuable resources to meet the increasing demands for pigmented rice as functional healthy foods.

In conclusion, overall, the present study results over a valuable upland red rice genetic resource with a high variation of grain physical characters and nutritional values. These included grain length, grain shape, percentage of head rice, percentage of large broken kernel, percentage of small broken kernel, amylose content, and anthocyanin content. This highly diverse germplasm can be selected and directly used to meet the rice consumer's needs for functional healthy foods. The germplasm with desirable traits can also be used to assemble new improved upland red rice varieties with various superior traits, which may accommodate a wider range of rice consumer's needs and preferences.

\section{ACKNOWLEDGEMENTS}

This research was financially supported by The Indonesian Ministry of Research, Technology and Higher Education through Hibah Penelitian Terapan Unggulan Perguruan Tinggi 2017. We thank the Director of DRPM Kemenristekdikti for providing the funding support. We also extend our thanks to Andreas Bouk and Oktovianus Kehi Asa for providing us with the rice seeds from the field for laboratory analysis.

\section{REFERENCES}

Abdel-Aal E-SM, Young CJ, Rabalsk I. 2006. Anthocyanin composition in black, blue, pink, purple, and red cereal grains. J Agric Food Chem 54: 4696-4704.

Astuti1 M, Kanoni S, Mustika M, Krisbianto O. 2017. Commercial, cooking, and eating quality traits and nutrient values of local mixed black and white rice from Yogyakarta. Indonesian Food and Nutrition Progres 14 (2): 118-127.

Banjerdpongchai R, Wudtiwai B, Sringarm K. 2013. Cytotoxic and apoptotic-inducing effects of purple rice extracts and chemotherapeutic drugs on human cancer cell lines. Asian Pac J Cancer Prev 14 (11): 6541-654. DOI: 10.7314/APJCP.2013.14.11.654.

Bhonsle SJ, Sellappan K. 2010. Agriculture grain quality evaluation of traditionally cultivated rice varieties of Goa, India. Recent Research in Science and Technology 2 (6): 88-97.

BPS NTT. 2020. Provinsi Nusa Tenggara Timur Dalam Angka 2020. Badan Pusat Statistik Provinsi Nusa Tenggara Timur, Kupang.

BSN. 2008. Standar Nasional Indonesia. SNI: 6128, Beras. Badan Standardisasi Nasional. Jakarta. [In Indonesian]

Chen M-H, McClung AM, Bergman CJ. 2016. Concentrations of ligomers and polymers of proanthocyanidins in red and purple rice bran and their relationships to total phenolics, flavonoids, antioxidant capacity, 
and whole-grain color. Food Chem 208: 279-87. DOI: 10.1016/j.foodchem.2016.04.004

Chen X, Zhou X, Yang Z, Gu C, Tao Y, Guo Q, Guo D, Zhang H, Xu P, Liao Y, Wang Y, Duan Q, Ran X, Wang L, Li Y and Wu X. 2019 Analysis of quality involving in minerals, amylose, protein, polyphenols and antioxidant capacity in different colored rice varieties. Food Sci Technol Res 25 (1): 141-148. DOI: 10.3136/fstr.25.141.

Delwiche SR, Bean MM, Miller RE, Webb BD, Williams PC. 1995. Apparent amylose content of milled rice by Near-Infrared Reflectance Spectrophotometry. Cereal Chem 72(2):182-187.

Giusti, MM, Wrolstad RE. 2000. Characterization and measurement of anthocyanins by UV-Visible spectrophotometry. John Wiley and Son. Inc, New York

Hanifa AP, Millner JP, McGill CRM, Sjahril R. 2020.Total anthocyanin, flavonoid and phenolic content of pigmented rice landraces from South Sulawesi. IOP Conf. Ser.: Earth Environ Sci 484: 012036. DOI: $10.1088 / 1755-1315 / 484 / 1 / 012036$.

Henderson AJ, Ollila AC, Kumar A, Borresen EC, Raina K, Agarwal R, Ryan EP. 2012. Chemopreventive properties of dietary rice bran: current status and future prospects. Adv Nutr 3: 643-53. DOI: 10.3945/an.112.002303.

Humaira A, Murtaza I, Nazir N, Wani AB, Naqash S, and Husaini AM. 2017. Nutritional profiling of pigmented and scented rice mir genotypes of Kashmir Himalayas. Int J Pharmacogn Phytochem 6 (6): 910-916.

Hyun JW, Chung HS, 2004. Cyanidin and malvidin from Oryza sativa cv. Heugjinjubyeo mediate cytotoxicity against human monocytic leukemia cells by arrest of G2/M phase and induction of apoptosis. J Agric Food Chem 52: 2213-2217. DOI: 10.1021/ff030370h.

IAARD (Indonesian Agency for Agricultural Research and Development).2012. Newly released superior rice varieties. Warta Penelitian Pertanian 34 (1): 8-9. [Indonesian]

Ichikawa H, Ichiyanagi T, Xu B, Yoshii Y, Nakajima M, Konishi T. 2001. Antioxidant activity of anthocyanin extracts purple black rice. J Med Food 4 (4): 211-8. DOI: 10.1089/109662001527444881.

Indonesian Ministry of Agriculture. 2009a. The release of local upland red rice variety Segreng as superior variety Segreng Handayani. Ministry of Agriculture Decree No.2226/Kpts/SR.120/5/2009, 19 May 2009. Indonesian Ministry of Agriculture, Jakarta.

Indonesian Ministry of Agriculture. 2009b. The release of local upland red rice variety Mandel as Superior Variety Mandel Handayani. Ministry of Agriculture Decree No.2227/Kpts/SR.120/5/2009, 19 May 2009. Indonesian Ministry of Agriculture, Jakarta.

IRRI [International Rice Research Institute]. 1988. Standard Evaluation System for Rice. IRRI, Los Banos, Philippines

Juliano B.O. 1993. Rice in Human Nutrition. Food and Agriculture Organization of the United Nations, Rome.

Juliano BO. 1971. A simplified assay for milled-rice amylose. Cereal Sci Today 16: 334-340.

Juliano BO. 1979. Amylose analysis in rice - A review. Proceeding Workshop on Chemical Aspects of Rice Grain Quality, Los Banos, Philippines.

Kim CK, Cho MA, Choi YH, Kim JA, Kim YH, Kim YK.2011. Identification and characterization of seed-specific transcription factors regulating anthocyanin biosynthesis in black rice. J Appl Genet 52 (2): 161-169. DOI: 10.1007/s13353-011-0027-3

Kim DK, Park S, Lee JY, Ha, Lee SH JG, Lim SH. 2018. A rice B-Box protein, OsBBX14, finely regulates anthocyanin biosynthesis in rice. Intl J Mol Sci 19: 2190. DOI: 10.3390/ijms19082190.

Kristamtini, Purwaningsih H. 2009. Potensi pengembangan beras merah sebagai plasma nutfah Yogyakarta. Jurnal Litbang Pertanian 28 (3): 88-95. [Indonesian]

Lalel HJD, Abidin Z, Jutomo L. 2009. Sifat fisiko kimia beras merah gogo lokal Ende. Jurnal Teknologi dan Industri Pangan 20 (2): 109-116. [Indonesian]

Lee HS, Oh SK, Choi HC, and Kim SU. 1998. Identification of anthocyanins from pigmented rice seed. Agric Chem Biotechnol 41: 257-260.

Lim SH, Ha SH, 2013. Marker development for the identification of rice seed color. Plant Biotechnol Rep 7: 391-398.

Mardiah Z, Septianingrum E, Handoko DD, Kusbiantoro B. 2017 Improvement of red rice-eating quality through one-time polishing process and evaluation on its phenolic and anthocyanin content. Intl J Agric For Plantation 5: 22-28.
Mau YS, Ndiwa ASS, Markus JER, Oematan SS, Nasution A, Handoko DD, Makbul K. 2017. Genetic diversity of red and black upland rice accessions from East Nusa Tenggara, Indonesia as revealed by agromorphological characters. Biodiversitas 18 (1): 197-211. DOI: 10.13057/biodiv/d180127.

Mau YS, Ndiwa ASS, Markus JER, Oematan SS, Nasution A, Handoko DD, Makbul K. 2018. Blast resistance levels of red and black upland rice local cultivars from Indonesia. Asian J Crop Sci 10 (2): 53-65. DOI: 10.3923 ajcs.2018

Mau YS, Ndiwa ASS, Markus JER, Oematan SS. 2019. Drought tolerance indices for selection of drought-tolerant, high-yielding upland rice $\begin{array}{llllllll}\text { genotypes. Austr J Crop Sci } 10 & \text { (3): 170-178. DOI: }\end{array}$ 10.21475/ajcs.19.13.01.p1778

Mau YS, Ndiwa ASS, Oematan SS 2020. Brown spot disease severity, yield and yield loss relationships in pigmented upland rice from East Nusa Tenggara, Indonesia. Biodiversitas 21 (4): 2625-2634. DOI: 10.13057/biodiv/d210443

Muntana N, Prasong S. 2010. Study on total phenolic content and their antioxidant activities of the white, red and black rice bran extracts. J Biol Sci 13: 170-174. DOI: 10.3923/pjbs.2010.170.174.

Nam SH, Choi SP, Kang MY, Koh HJ, Kozukue N, Friedman M. 2006. Antioxidative activities of bran from twenty-one pigmented rice cultivars. Food Chem 94: 613-620.

Ndiwa ASS, Mau YS. 2019. Yield and yield component performances of local pigmented upland rice cultivars from East Nusa Tenggara, Indonesia in three locations. Tropical Drylands 3(2): 49-55. DOI: $10.13057 /$ tropdrylands/t030203.

Oikawa T. Maeda H, Oguchi T, Yamaguchi T. Tanabe N, Ebana K, Yano M, Ebitani T, Izawa T. 2015. The birth of a black rice gene and its local spread by introgression. Plant Cell 27: 2401-2414. DOI: 10.1105/tpc. 15.00310 .

Pojer E, Mattivi F, Johnson D, Stockley CS. 2013. The case for anthocyanin consumption to promote human health: a review. Compr Rev Food Sci Food Saf 12 (5): 483-508. DOI: 10.1111/15414337.12024.

Ponnappan S, Thangavel A, Sahu O. 2017. Milling and physical characteristics of pigmented rice varieties. Intl J Food Chem 1 (1): 2429. DOI: $10.11648 /$ j.ijfc.20170101.15.

Prior R, Cao G, Martin A, Sofic E, McEwen J, O"Brien C, Lischner N, Ehlenfeldt M, Kaalt W, Krewer G, and Mainland CM. 1998. Antioxidant capacity as influenced by total phenolic and anthocyanin content, maturity of Vaccinium species. J. Agric Food Chem 46: 2686-2693. DOI: $10.1021 / \mathrm{j} f 980145 \mathrm{~d}$.

Priya TSR, Nelson ARLE, Ravichandran K, Antony U. 2019. Nutritional and functional properties of colored rice varieties of South India: a review. J Ethnic Foods 6: 1-11. DOI:10.1186/s42779-019-0017-3.

Sakulsingharoj C, Inta P, Sukkasem R, Pongjaroenkit S, Chowpongpang S, Sangtong V. 2016. Cloning and characterization of OSBl gene controlling anthocyanin biosynthesis from Thai black rice. Genomics and Genetics 9 (1): 7-18. DOI: 10.14456/gag.2016.2.

Santika A., Rozakurniati, 2010. Teknik evaluasi mutu beras ketan dan beras merah pada beberapa galur padi gogo. Buletin Teknik Pertanian 15 (1): 1-5. [Indonesian].

Satue-Gracia MT, Heinonen M, Frankel EN. 1997. Anthocyanins as antioxidants on human low-density lipoprotein and lecithin liposome systems. J Agric Food Chem 45: 3362-3367. DOI: $10.1021 / \mathrm{j} f 970234 \mathrm{a}$.

Shao Y, Xu F, Sun X, Bao J, Beta T. 2014. Identification and quantification of phenolic acids and anthocyanins as antioxidants in bran, embryo and endosperm of white, red, and black rice kernels (Oryza sativa L.). J Cereal Sci 59: 211-218.

Shih CH, Chu H, Tang LK, Sakamoto W, MaekawaM, Chu IK, Wang M, Lo C. 2008. Functional characterization of key structural genes in rice flavonoid biosynthesis. Planta 228: 1043-1054. DOI: 10.1016/j.jcs.2014.01.004.

Shilpa JB, Sellappan K. 2010. Grain quality evaluation of traditionally cultivated rice varieties of Goa, India. Recent Res Sci Technol 2 (6): 88-97.

Suliartini NWS, Sadimantara GR, Wijayanto T, Muhidin. 2011. Pengujian kadar antosianin padi gogo beras merah hasil koleksi plasma nutfah Sulawesi Tenggara. Crop Agro 4 (2): 43-48.

Sun X, Zhang Z, Chen C, Wu W, Ren N, Jiang C, Yu J, Zhao Y, Zheng X, Yang Q. 2018. The $C-S-A$ gene system regulates hull pigmentation and reveals the evolution of anthocyanin biosynthesis pathway in rice. J Exp Bot 69: 1485-1498. DOI: 10.1093/jxb/ery001. 
Sweeney MT, Thomson MJ, Pfeil BE, McCouch S. 2006. Caught redhanded: $R c$ encodes a basic helix-loop-helix protein conditioning red pericarp in rice. Plant Cell 18: 283-294. DOI: 10.1105/tpc. 105.038430 .

Tsuda T, Horio F, and Osawa T. 2002. Cyanidin 3-O-a-glucoside suppresses nitric oxide production during a zymosan treatment in rats. J Nutr Sci Vitaminol 48: 305-310. DOI: 10.3177/jnsv.48.305.

Widyawati PS, Suteja AM, Suseno TIP, Monika M, Saputrajaya W, Liguori C. 2014. Effect of pigment color difference in organic rice on antioxidant activity. Agritech 34 (4): 399-406. DOI: 10.22146/agritech.9434 [Indonesian].

Yawadio R, Tanimori S, Morita N. 2007. Identification of phenolic compounds isolated from pigmented rice and their aldose reductase inhibitory activities. Food Chem 101 (4): 1616-1625. DOI: 10.1016/j.foodchem.2006.04.016.

Zhao C, Giusti MM, Malik M, Moyer MP, Magnuson BA. 2004. Effects of commercial anthocyanin-rich extracts on colonic cancer and nontumorigenic colonic cell growth. J Agric Food Chem 52: 61226128. DOI: $10.1021 /$ jf049517a. 